\title{
The Efforts to Improve Shear Strength of Clay Soil Using Plastic Waste
}

\author{
Endaryanta, Dian EksanaWibowo \\ Dept. of Civil Engineering and Planning Education \\ Faculty of Engineering, Yogyakarta State University \\ Yogyakarta, Indonesia \\ endaryanta@gmail.com,dian.eksana@uny.ac.id
}

\begin{abstract}
Plastic wastes could threaten the ecosystem of the environment because it is non-biodegradable material. The efforts to reduce the plastic trash are taken by 3R-way (Reuse, Reduce, Recycles). How to recycle for example by the use of plastic trash: to make oils, as a composites for construction, for example: as the fiber in the concrete, and as a fiber for soil reinforcement. We will try to reinforcement of clay by using plastic trash to increase of the shear strength of clay. Plastic trash is cut into small pieces with $1 \times 1(\mathrm{~cm})$ and $1 \times 0,5(\mathrm{~cm})$ size mixed with clay, compacted, and then tested in the laboratory by Unconfined Compressive Test. Plastic trash using of the former mineral water containers (PET plastic types). The results of this research showed that the addition of small pieces of the plastic trash in clay: (1) will increase the value of qu (unconfined compressive strength) of soil at the rate of $3 \%$ of plastic on Kasongan clay, and only if the plastic is large cutting $(1 \times 1) \mathrm{cm}$ on Wates clay. (2) will increase the internal friction-angle $\varphi$ if the plastic content of $3 \%$ (Kasongan clay) and Wates clay but only if the plastic is large cutting $(1 \times 1) \mathrm{cm}$. (c) will increase of the soil friction if at the rate of $2 \%$ of plastic (Kasongan clay), will increase of the soil friction if the small size $(0,5 \times 1) \mathrm{cm}$ of plastic pieces (Wates clay).
\end{abstract}

Keywords-plastic trash, clay, unconfined compressive test, direct shear test

\section{INTRODUCTION}

Waste is a complex issue that can be found alongside the industrial growth and increasing population. Not only bringing many diseases, waste can also be the source of environmental pollution even the slum area. There are numerous efforts that have been done to overcome those problems, such as build landfills and waste incinerator, however these measures are causing even more new problems which are air pollution and controversy from the neighbourhood people.

Plastic waste is a type of inorganic waste which is difficult to decompose and cannot be recycled, for example is cups or container made from plastic.

People in Indonesia produces about 2.5 litres of waste in a day or 625 million litres waste from total population. This condition will continue to grow each year. Approximate volume of waste in Indonesia in 2008 reach 38.5 million ton/year which is consist of organic waste $(58 \%)$, plastic waste $(14 \%)$, paper waste $(9 \%)$ and wood waste $(4 \%)$. Plastic waste is the most important issue concerning the environment in the world and also Indonesia. There are several data from Kementrian Lingkungan Hidup (The Ministry of Environment) found that the number of plastic waste in Indonesia reach 26.500 ton per day. This condition threatens the environment because plastic in a non-biodegradable ( $\mathrm{K}$ Sa'diyah, Sri Rachmania Juliastuti, 2013).

According to data from Ministry of Environment in 2012, the amount of waste in 14 biggest cities in Indonesia is 1.9 million ton. Furthermore, the amount of plastic waste in 2013 is $53 \%$ of total waste. (Syamsiro, 2013).

Several efforts which can be done to decrease the amount of plastic waste are $4 \mathrm{R}$, which are reuse, reduce, recycle, and replace (Labib Naufaldi, 2013). Recycle can be done by utilize the plastic waste into composite and additional construction materials. Another example is plastic waste can be used as materials to increase the shear and stress power into the soil. Therefore, this research attempts to utilize plastic waste like mineral water cups or containers made from plastic as the admixture to improve the clay's properties.

The result of this study expects to: (a) reduce the volume of plastic waste produced by people. (b) improve the clay's properties in order to increase the shear strength and compression strength to gain more stable building construction.

Scope of data: a. Clay from Kasongan, Bantul and Punukan, Wates ( Jl. Wates km.7), Kulonprogo on $-0.30 \mathrm{~m}$ altitude. Admixture: plastic waste in the form of mineral water cups that have been cut into jagged edgesin $1 \mathrm{~cm} \times 0.5 \mathrm{~cm} ; 1$ $\mathrm{cm} \times 1 \mathrm{~cm}$ with $0 \%, 1,2 \%, 3 \%$ percentages toward the weight of dry soil. These small dimensions are used so that the expected result can be more homogenous.

\section{Literary Review}

1) Soil

In civil engineering, basic soil is an important and crucial construction's component. Good soil is a soil that has high strong support and good soil's properties, however not all soil have these conditions. Clay contains mineral (called clay 
mineral) which is montmorillonite, illite, kaolinite, palygorskite, chlorite, vermiculite, and halloysite (Hardiyatmo, 2002). Clay that has more montmorillonite than the others will have expansive property that damaging the road's construction or other buildings that built on this clay.

\section{2) Clay Improvement}

Clay improvement is an effort made so that the soil has good technical properties, which is stronger, decreased permeability, and volume change. Mechanical stability is a clay improvement method in which can be formed in compaction, soil change, soil mixing such as mixed with cement (Feri Safaria, 2004). Clay improvement or clay stabilization can also be done in chemical method, for example is mixing soil with cement, fly ash, and grouting (Suryolelono, 2005), mixing soil with sand and rise husk ash (Mirzan Ludvian \& Dian Eksana W.,2017) .

Clay has quite bad soil's properties. It has low strongsupport, high expansive property, cohesive, and high compressibility causing deformation.

\section{3) Plastic waste}

There are a lot of types of plastic, such as PET, HDPE, PVC, LDPE, PP, PS and others. The amount of midden in Indonesia in 2008 reach 38.7 million ton/year which largely consists of organic waste $(58 \%)$, plastic waste $(14 \%)$, paper waste $(9 \%)$, and wood waste $(4 \%)$. One of the main issues of environment in the world and Indonesia is plastic waste. Data found in The Ministry of Environment refer that the amount of plastic waste comes to 26.500 ton per day. Furthermore, the plastic that we used today is non-biodegradable.

Research about the benefit of plastic waste that has been conducted is modifying plastic waste into fuel oil, for example, the research that has been conducted by Fairuz Hilwa and Bayu Indrawan (http://www.slideshare.net/ and http://olahsampah.com). Plastic waste can also be used to improve concrete's quality (Fitroh Fauzi Ridwan,et al,2014).

Another research about plastic waste is research by Sazuatmo,2011 (FT. Unihaz, Bengkulu), he indicates that shredded plastic waste can be used to increase the shear strength of soil. The value of c, shear strength can increased, also fluctuating angle of frictions. However, there is a crucial limitation or problem found in this research, that is the difficulty to print test-object to shear test. Hence, the result is fluctuating (not stable).

\section{METHOD}

Research using experiment method, see Fig.1.

Population in this research are clays from Kasongan, Bantul and Punukan, Wates ( Jl. Wates km.7), Kulonprogo on $-0.30 \mathrm{~m}$ altitude. The clays are taken from each places so that the properties of the clay will be the same for one test object. Plastic waste that we used is PET type plastic from mineral water bottles.

Purposive sampling was used to determine the sample because plastic bottles of mineral water are easily found in neighbourhood and there are many damaged roads caused by clay. There are total 32 test samples $(2 \times 4 \times 2 \times 2)$ because there are 2 variations of clay's sources, 4 variations of mixture percentages, 2 variations of plastic's shapes, and the research conducted two times.

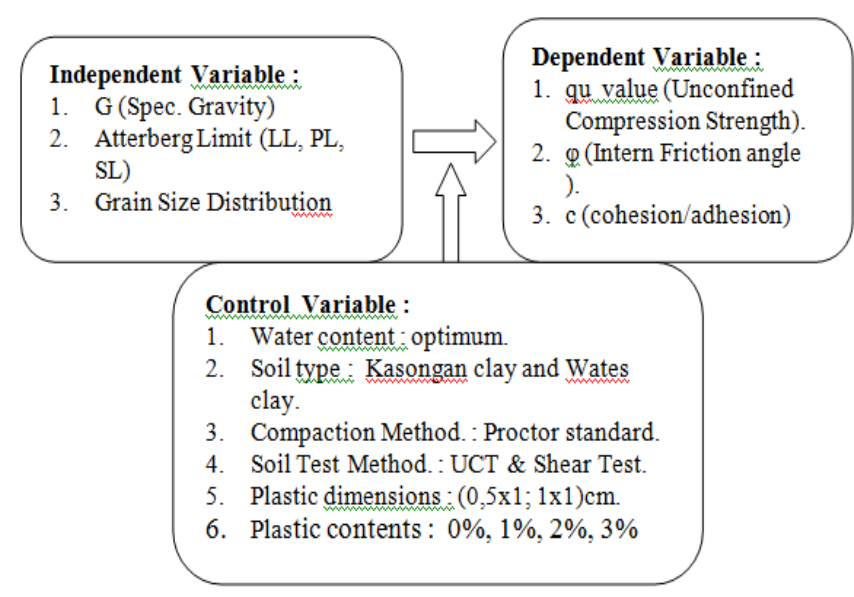

Fig. 1. Variety of Experiment Research Variables

This research experiment was conducted in 2 steps, Initial Test and Core Test. The initial test consists of the measuring BJ (G), Atterberg limits (LL, PL, SL), particle size distribution, optimum moisture content, and producing plastic's pieces for the mixture. We used ASTM Standard test (Annual Book of ASTM Standards, 1997). The core test conducted in form of Unconfined Compression Test in FT UNY Soil Mechanics Laboratory. The instruments used are:

1. One set of particle size distribution measuring tools (soil filter, hydrometer, and others) (ASTM D422-72, 2007).

2. Liquid limits and Plastic limits test equipment set (ASTM) D423, 424-72).

3. Water content test equipment set(scale, oven, and others)(ASTM D2216-71 (1989).

4. Soil Laboratory compaction test equipment set (ASTM D698-70 (1989).

5. One set of Unconfined Compression Test equipment (ASTM D-2166-91).

The purpose of this test (ASTM D-2166-91) is to determine the unconfined compression strength value (qu), the value of internal angle friction $(\varphi)$ and cohesion $\mathrm{c}$ of soil. Unconfined compression strength is the amount of axial pressure $\left(\mathrm{kg} / \mathrm{cm}^{2}\right)$ required to break one soil cylinder or shorten $20 \%$ (if the clay won't break). The formula used are:

$$
\begin{aligned}
& \mathrm{A}=\mathrm{Ao} /(1-\varepsilon) \quad(\mathrm{cm} 2), \\
& \varepsilon=\Delta \mathrm{L} / \mathrm{Lo}, \\
& \sigma \max =\mathrm{qu}=\mathrm{Pmax} / \mathrm{A} \quad\left(\mathrm{kg} / \mathrm{cm}^{2}\right) \\
& \varphi=2\left(\alpha-45^{\circ}\right) \\
& \mathrm{c}=\mathrm{qu} / 2 \operatorname{tg} \alpha \quad\left(\mathrm{kg} / \mathrm{cm}^{2}\right)
\end{aligned}
$$

Descriptive and comparative model are used as research's experiment design, which is determine and compare the value of shear strength and unconfined compression strength (qu, $\varphi$ dan c) original soil and mixture of plastic waste and 2 variations of soil's sources, 4 variations of mixture 
composition, and 2 variations of shape. Experiment designs are arranged in Table I.

\section{TABLE I. TABLE DESIGN OF EXPERIMENTS}

\begin{tabular}{|c|c|c|c|c|}
\hline \multicolumn{5}{|c|}{ 1a. UNCONFINED COMPRESSION TEST } \\
\hline $\begin{array}{c}\text { Composition mixture ( } \\
\text { weight ratio ) of } \\
\text { Clay : Plastic }=\end{array}$ & $\begin{array}{l}\text { Sum of } \\
\text { Sample } \\
\text { Number }\end{array}$ & $\begin{array}{c}\text { Intern } \\
\text { friction } \\
\text { angle }\end{array}$ & $\begin{array}{c}\text { Cohesion } \\
\text { /adhesion } \\
\text { of soil } \\
\end{array}$ & $\begin{array}{l}\text { Unconfined } \\
\text { Compress. } \\
\text { strength } \\
\end{array}$ \\
\hline & & $\varphi$ & $c$ & $q u$ \\
\hline $\begin{array}{c}\text { a. Kasongan clay } \\
1 \mathrm{C}+0 \% \mathrm{P} 1 \text { (initial } \\
\text { Clay) } \\
1 \mathrm{C}+1 \% \mathrm{P} 1 \\
1 \mathrm{C}+2 \% \mathrm{P} 1 \\
1 \mathrm{C}+3 \% \mathrm{P} 1 \\
1 \mathrm{C}+0 \% \mathrm{P} 2 \text { (initial } \\
\text { Clay) } \\
1 \mathrm{C}+1 \% \mathrm{P} 2 \\
1 \mathrm{C}+2 \% \mathrm{P} 2 \\
1 \mathrm{C}+3 \% \mathrm{P} 2\end{array}$ & $\begin{array}{l}2 \\
2 \\
2 \\
2 \\
2 \\
2 \\
2 \\
2 \\
2\end{array}$ & $\begin{array}{l}\Phi 01 \mathrm{~K} \\
\varphi 11 \mathrm{~K} \\
\varphi 21 \mathrm{~K} \\
\varphi 31 \mathrm{~K} \\
\varphi 02 \mathrm{~K} \\
\varphi 12 \mathrm{~K} \\
\varphi 22 \mathrm{~K} \\
\varphi 32 \mathrm{~K}\end{array}$ & $\begin{array}{l}\mathrm{c} 01 \mathrm{~K} \\
\mathrm{c} 11 \mathrm{~K} \\
\mathrm{c} 21 \mathrm{~K} \\
\mathrm{c} 31 \mathrm{~K} \\
\mathrm{c} 02 \mathrm{~K} \\
\mathrm{c} 12 \mathrm{~K} \\
\mathrm{c} 22 \mathrm{~K} \\
\mathrm{c} 32 \mathrm{~K}\end{array}$ & $\begin{array}{l}\text { qu01K } \\
\text { qu11K } \\
\text { qu21K } \\
\text { qu31K } \\
\text { quo2K } \\
\text { qu12K } \\
\text { qu22K } \\
\text { qu32K }\end{array}$ \\
\hline $\begin{array}{c}\text { b. Wates clay } \\
1 \mathrm{C}+0 \% \mathrm{P} 1 \text { (initial } \\
\text { Clay) } \\
1 \mathrm{C}+1 \% \mathrm{P} 1 \\
1 \mathrm{C}+2 \% \mathrm{P} 1 \\
1 \mathrm{C}+3 \% \mathrm{P} 1 \\
1 \mathrm{C}+0 \% \mathrm{P} 2 \text { (initial } \\
\text { Clay) } \\
1 \mathrm{C}+1 \% \mathrm{P} 2 \\
1 \mathrm{C}+2 \% \mathrm{P} 2 \\
1 \mathrm{C}+3 \% \mathrm{P} 2 \\
\end{array}$ & $\begin{array}{l}2 \\
2 \\
2 \\
2 \\
2 \\
2 \\
2 \\
2\end{array}$ & $\begin{array}{c}\Phi 01 \mathrm{~W} \\
\varphi 11 \mathrm{~W} \\
\varphi 21 \mathrm{~W} \\
\varphi 31 \mathrm{~W} \\
\varphi 02 \mathrm{~W} \\
\varphi 12 \mathrm{~W} \\
\varphi 22 \mathrm{~W} \\
\varphi 32 \mathrm{~W}\end{array}$ & $\begin{array}{l}\text { C01W } \\
\text { c11W } \\
c 21 W \\
c 31 W \\
c 02 W \\
c 12 W \\
c 22 W \\
c 32 W\end{array}$ & $\begin{array}{l}\text { qu01W } \\
\text { qu} 11 \mathrm{~W} \\
\text { qu21W } \\
\text { qu31W } \\
\text { qu} 02 \mathrm{~W} \\
\text { qu12W } \\
\text { qu22W } \\
\text { qu32W }\end{array}$ \\
\hline \multicolumn{5}{|c|}{ 1.b. DIRECT SHEAR TEST } \\
\hline $\begin{array}{l}\text { Composition } \\
\text { mixture ( weight } \\
\text { ratio ) of }\end{array}$ & $\begin{array}{l}\text { Sum of } \\
\text { Sample } \\
\text { Number }\end{array}$ & $\begin{array}{c}\text { Intern } \\
\text { friction } \\
\text { angle } \\
\end{array}$ & $\begin{array}{c}\text { Cohesion } \\
\text { /adhesion } \\
\text { of soil } \\
\end{array}$ & $\begin{array}{l}\text { Shear } \\
\text { Strength } \\
\text { values } \\
\end{array}$ \\
\hline Clay $:$ Plastic $=$ & & $\varphi$ & $c$ & $\tau u$ \\
\hline $\begin{array}{c}\text { a. Kasongan clay } \\
1 \mathrm{C}+0 \% \mathrm{P} 1 \text { (initial } \\
\text { Clay) } \\
1 \mathrm{C}+1 \% \mathrm{P} 1 \\
1 \mathrm{C}+2 \% \mathrm{P} 1 \\
1 \mathrm{C}+3 \% \mathrm{P} 1 \\
1 \mathrm{C}+0 \% \mathrm{P} 2 \text { (initial } \\
\text { Clay) } \\
1 \mathrm{C}+1 \% \mathrm{P} 2 \\
1 \mathrm{C}+2 \% \mathrm{P} 2 \\
1 \mathrm{C}+3 \% \mathrm{P} 2 \\
\end{array}$ & $\begin{array}{l}3 \\
3 \\
3 \\
3 \\
3 \\
3 \\
3 \\
3\end{array}$ & $\begin{array}{l}\Phi 01 K \\
\varphi 11 K \\
\varphi 21 K \\
\varphi 31 K \\
\varphi 02 K \\
\varphi 12 K \\
\varphi 22 K \\
\varphi 32 K\end{array}$ & $\begin{array}{l}\mathrm{c} 01 \mathrm{~K} \\
\mathrm{c} 11 \mathrm{~K} \\
\mathrm{c} 21 \mathrm{~K} \\
\mathrm{c} 31 \mathrm{~K} \\
\mathrm{c} 02 \mathrm{~K} \\
\mathrm{c} 12 \mathrm{~K} \\
\mathrm{c} 22 \mathrm{~K} \\
\mathrm{c} 32 \mathrm{~K}\end{array}$ & $\begin{array}{l}\tau u 01 \mathrm{~K} \\
\tau \mathrm{u} 11 \mathrm{~K} \\
\tau \mathrm{u} 21 \mathrm{~K} \\
\tau \mathrm{u} 31 \mathrm{~K} \\
\tau \mathrm{u} \mathrm{o} 2 \mathrm{~K} \\
\tau \mathrm{u} 12 \mathrm{~K} \\
\tau \mathrm{u} 22 \mathrm{~K} \\
\tau \mathrm{u} 32 \mathrm{~K}\end{array}$ \\
\hline $\begin{array}{c}\text { b. Wates clay } \\
1 \mathrm{C}+0 \% \mathrm{P} 1 \text { (initial } \\
\text { Clay) } \\
1 \mathrm{C}+1 \% \mathrm{P} 1 \\
1 \mathrm{C}+2 \% \mathrm{P} 1 \\
1 \mathrm{C}+3 \% \mathrm{P} 1 \\
1 \mathrm{C}+0 \% \mathrm{P} 2 \text { (initial } \\
\text { Clay) } \\
1 \mathrm{C}+1 \% \mathrm{P} 2 \\
1 \mathrm{C}+2 \% \mathrm{P} 2 \\
1 \mathrm{C}+3 \% \mathrm{P} 2\end{array}$ & $\begin{array}{l}3 \\
3 \\
3 \\
3 \\
3 \\
3 \\
3 \\
3\end{array}$ & $\begin{array}{c}\Phi 01 \mathrm{~W} \\
\varphi 11 \mathrm{~W} \\
\varphi 21 \mathrm{~W} \\
\varphi 31 \mathrm{~W} \\
\varphi 02 \mathrm{~W} \\
\varphi 12 \mathrm{~W} \\
\varphi 22 \mathrm{~W} \\
\varphi 32 \mathrm{~W}\end{array}$ & $\begin{array}{l}\mathrm{C} 01 \mathrm{~W} \\
\mathrm{c} 11 \mathrm{~W} \\
\mathrm{c} 21 \mathrm{~W} \\
\mathrm{c} 31 \mathrm{~W} \\
\mathrm{c} 02 \mathrm{~W} \\
\mathrm{c} 12 \mathrm{~W} \\
\mathrm{c} 22 \mathrm{~W} \\
\mathrm{c} 32 \mathrm{~W}\end{array}$ & $\begin{array}{l}\tau u 01 \mathrm{~W} \\
\tau u 11 \mathrm{~W} \\
\tau u 21 \mathrm{~W} \\
\tau u 31 \mathrm{~W} \\
\tau u \quad 02 \mathrm{~W} \\
\tau u 12 \mathrm{~W} \\
\tau u 22 \mathrm{~W} \\
\tau u \quad 32 \mathrm{~W}\end{array}$ \\
\hline
\end{tabular}

\section{RESULT AND DISCUSSION}

\section{A. Results}

Clay's data and properties. Soil material research originated from Wates Kulonprogo and Kasongan, Bantul. Those parameter values, see Table II.
TABLE II. INITIAL PARAMETER SOIL TEST

\begin{tabular}{|l|l|l|}
\hline & \multicolumn{1}{|c|}{ Wates Clay } & \multicolumn{1}{c|}{ Kasongan Clay } \\
\hline G & 2,42 & 2,57 \\
W & $10,04 \%$ & $19,8 \%$ \\
LL & $47,7 \%$ & $60,0 \%$ \\
PL & $27,9 \%$ & $21,0 \%$ \\
SL & $12,4 \%$ & $16,0 \%$ \\
Type of soil & CL & $\mathrm{CH}$ \\
Activities,A & 0,71 & 0,68 \\
\hline
\end{tabular}

In original soil compaction test in laboratory using Proctor standard method, we obtain the optimum moisture content (OMC) and maximum dry density (MDD) are presented in Table III below:

TABLE III. VALUES OF OMC AND MDD ORIGINAL SOIL FROM WATES AND KASONGAN

\begin{tabular}{|l|l|l|}
\hline \multicolumn{1}{|c|}{ The Clay from : } & \multicolumn{1}{|c|}{ Wates } & \multicolumn{1}{c|}{ Kasongan } \\
\hline OMC & $31 \%$ & $24 \%$ \\
MDD & $1,29 \mathrm{gram} / \mathrm{cm}^{3}$ & $1,38 \mathrm{gram} / \mathrm{cm}^{3}$ \\
\hline
\end{tabular}

\section{1) Plastic Waste Data}

This research uses used mineral water plastic's bottles which have been cut into $1 \mathrm{~cm} \times 1 \mathrm{~cm}$ and $1 \mathrm{~cm} \times 0.5 \mathrm{~cm}$ square shape as the additive materials. The plastics' materials have 1.56 density (BJ or $\mathrm{G}$ ). The weights of plastic mixed are $0 \%, 1 \%, 2 \%$, and $3 \%$ toward soil weight. After producing the objects test and unconfined compression test' objects, then we perform the unconfined compression test. The results of the experiment are as follows.

\section{2) Unconfined Compression Test Result Data}

Define abbreviations and acronyms the first time they are used in the text, even after they have been defined in the abstract. Abbreviations such as IEEE, SI, MKS, CGS, sc, dc, and rms do not have to be defined. Do not use abbreviations in the title or heads unless they are unavoidable.

\section{B. Discussions}

Based on Unconfined Compression Test and Direct Shear Test above, we present the description using graphs

\section{1) Clays from Punukan, Wates}

The result of unconfined compression test on clays from Wates mixed with shredded plastic waste as follows. It is shown with the values of qu (unconfined compression strength value $(\mathrm{kg} / \mathrm{cm} 2))$, shear strength angle $(\varphi)$, and the cohesionadhesion (c, kg/cm2) in Fig. 2-7.

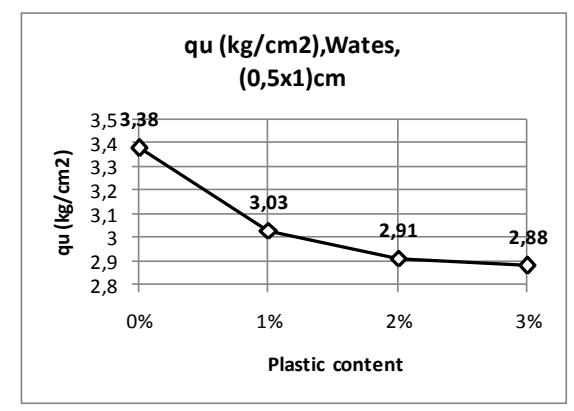

Fig. 2. Value qu Soil from Wates with plastic $(0,5 \times 1) \mathrm{cm}$ 


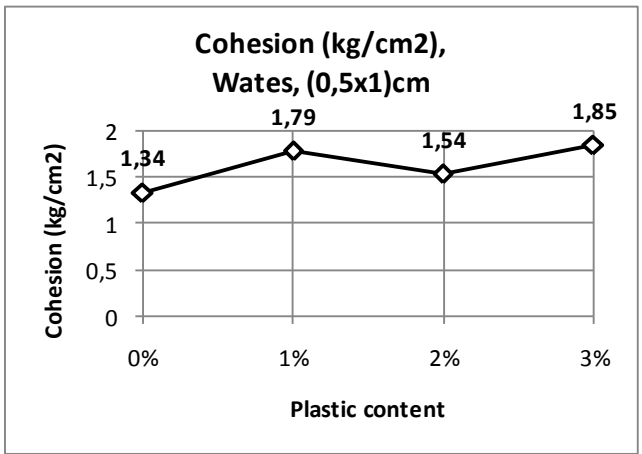

Fig. 3. Value cohesion Soil from Wates with plastic $(0,5 \times 1) \mathrm{cm}$

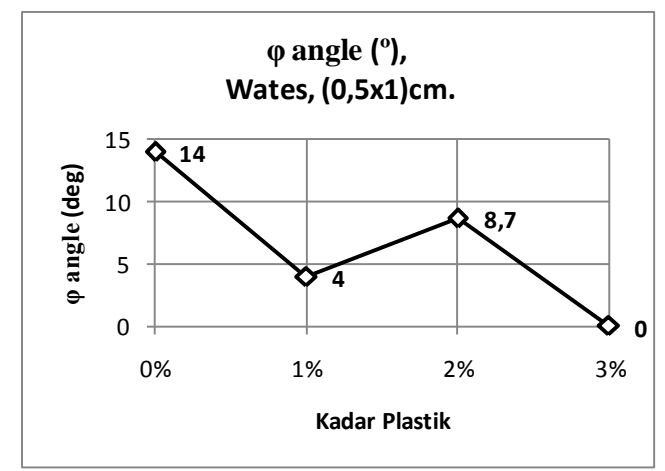

Fig. 4. Value $\phi$ Soil from Wates with plastic $(0,5 \times 1) \mathrm{cm}$

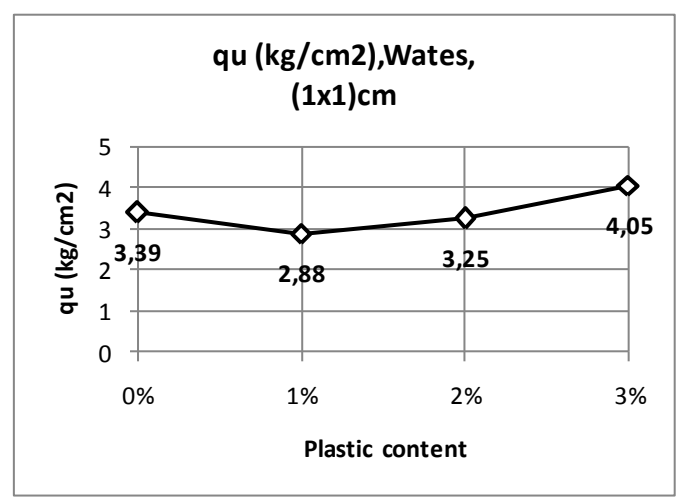

Fig. 5. Value qu Soil from Wates with plastic( $1 \times 1) \mathrm{cm}$

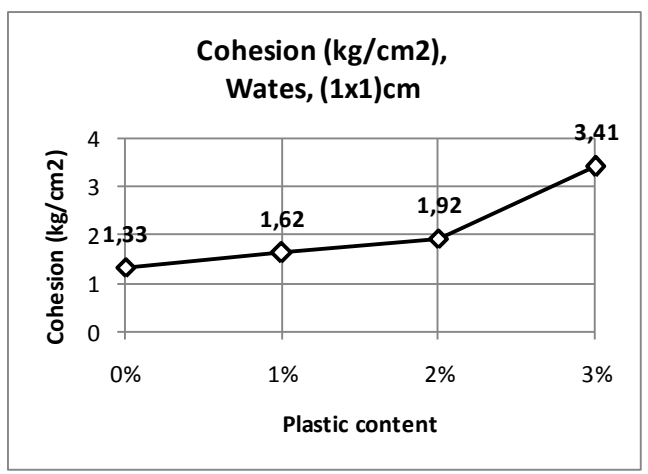

Fig. 6. Value cohesion Soil from Wates with plastic $(1 \mathrm{x} 1) \mathrm{cm}$

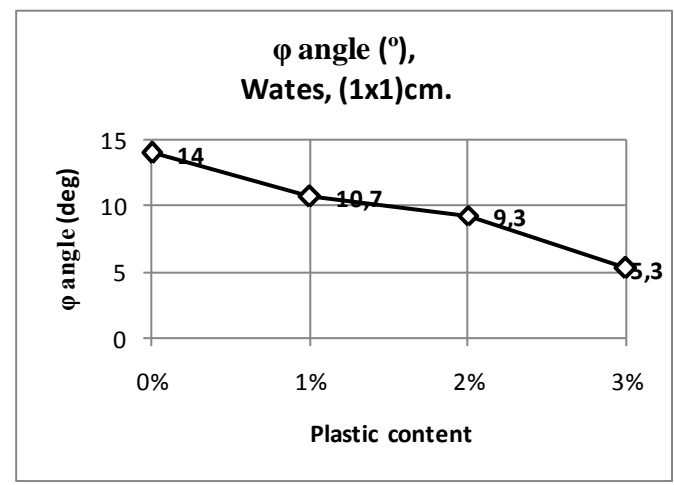

Fig. 7. Value $\phi$ Soil from Wates with plastic $(1 \times 1) \mathrm{cm}$

Based on unconfined compression test on clays from Based on shear strength test on clays from Wates, it indicates that:

1. The cohesion-adhesion will increased proportionally in addition of small plastics cuts $(0.5 \mathrm{~cm} \mathrm{x} 1 \mathrm{~cm})$ but it will decreased if the larger plastics cuts were added. It may be the caused by the plastics blocking the contact are between clays.

2. Internal friction angle $(\varphi)$ will decreased in addition of small plastics cuts $(0.5 \mathrm{~cm} \mathrm{x} 1 \mathrm{~cm})$ but $\varphi$ will increased if the larger plastics cuts were added. This caused by the number of jagged edges of the larger plastics cuts that increase the shear strength.

\section{2) Clays from Kasongan, Bantul}

The result of unconfined compression test on clays from Kasongan mixed with shredded plastic waste as follows. It is shown with the values of qu (unconfined compression strength value $(\mathrm{kg} / \mathrm{cm} 2))$, internal friction angle $(\varphi)$, and the adhesion (c, $\mathrm{kg} / \mathrm{cm} 2)$ in Fig.8-13.

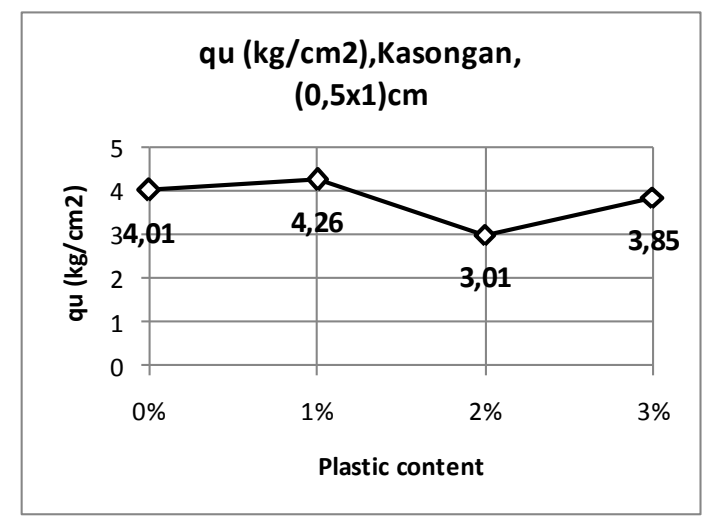

Fig. 8. Value qu Soil from Kasongan with plastic $(0,5 \times 1) \mathrm{cm}$ 


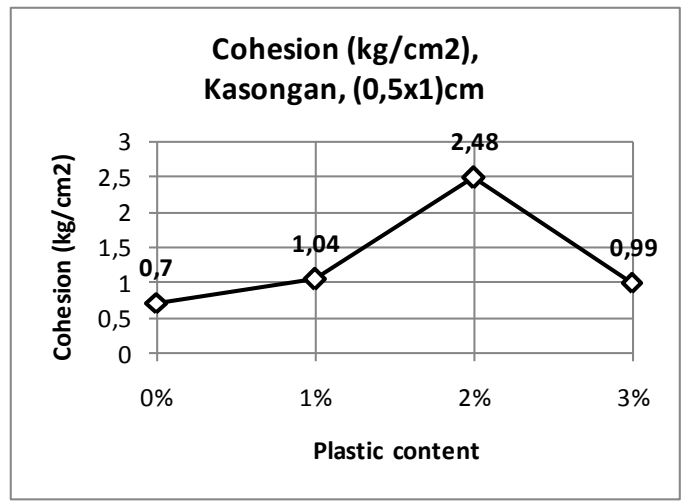

Fig. 9. Value Cohesion Soil from Kasongan with plastic $(0,5 \times 1) \mathrm{cm}$

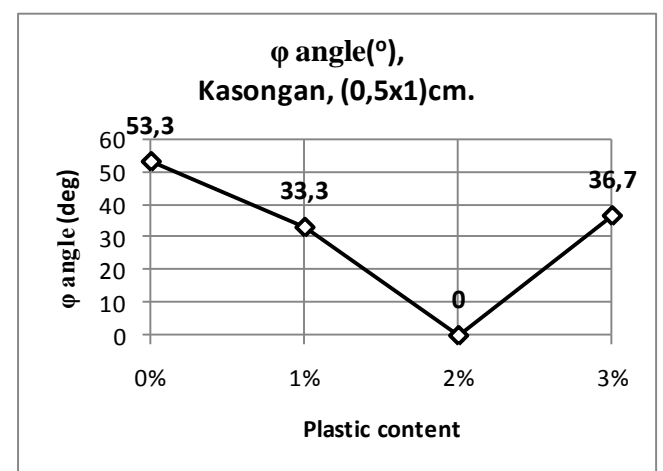

Fig. 10. Value $\phi$ Soil from Kasongan with plastic $(0,5 \times 1) \mathrm{cm}$

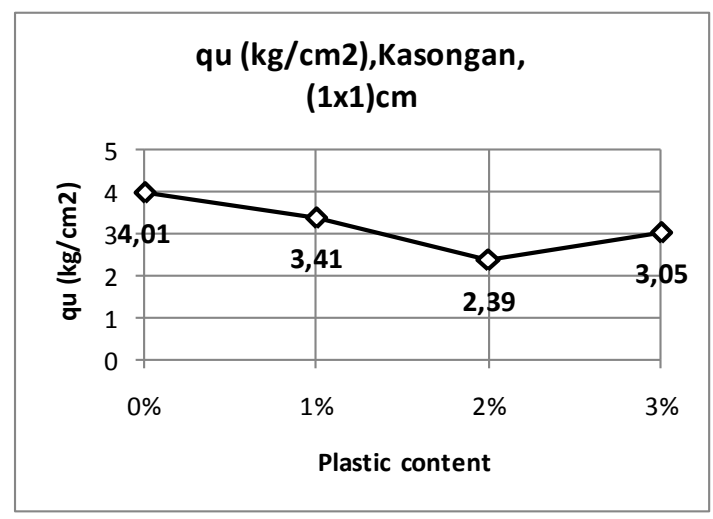

Fig. 11. Value qu Soil from Kasongan with plastic( $1 \times 1) \mathrm{cm}$

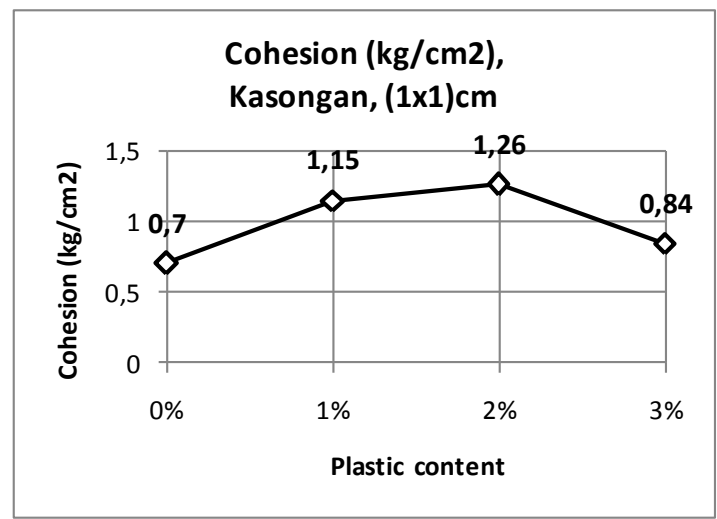

Fig. 12. Value Cohesion Soil from Kasongan with plastic $(1 \mathrm{x} 1) \mathrm{cm}$

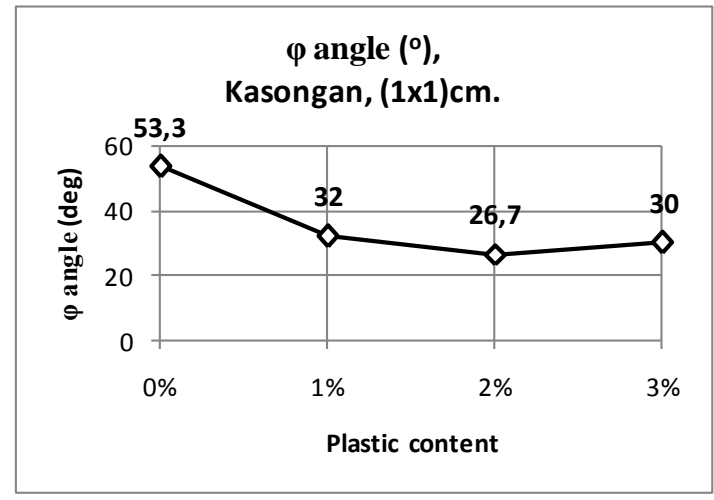

Fig. 13. Value $\phi$ Soil from Kasongan with plastic( $1 \times 1) \mathrm{cm}$

Based on unconfined compression test on clays from Kasongan above, it appears that:

1. The value of qu tend to decrease a little if the amount of plastics increased, however, when the plastic content is $3 \%$, the value of qu tend to increase. It may be due to the number of jagged edges on increased plastics content consecutively increasing the clay's compression strength.

2. Adding plastics will increased the adhesion then decreased. The highest cohesion-adhesion occurs when the optimum plastic content is $2 \%$.

3. Internal friction angle $(\varphi)$ will decreasing then increased. When the plastic contents is $3 \%$ or more, angle $(\varphi)$ tends to increase. It may be because of the quantity of jagged edges on increased plastic contents $(\geq 3 \%$ ) will also increasing clay's shear strength.

The result of shear strength test on clays from Kasongan mixed with shredded plastic waste as follows. It is shown with the values of internal friction angle $(\varphi)$ and cohesion-adhesion $\left(\mathrm{c}, \mathrm{kg} / \mathrm{cm}^{2}\right)$.

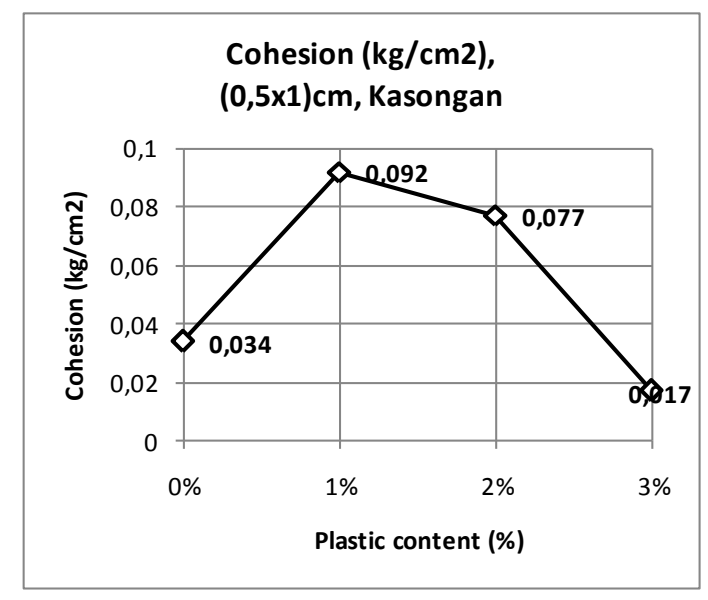

Fig. 14. 


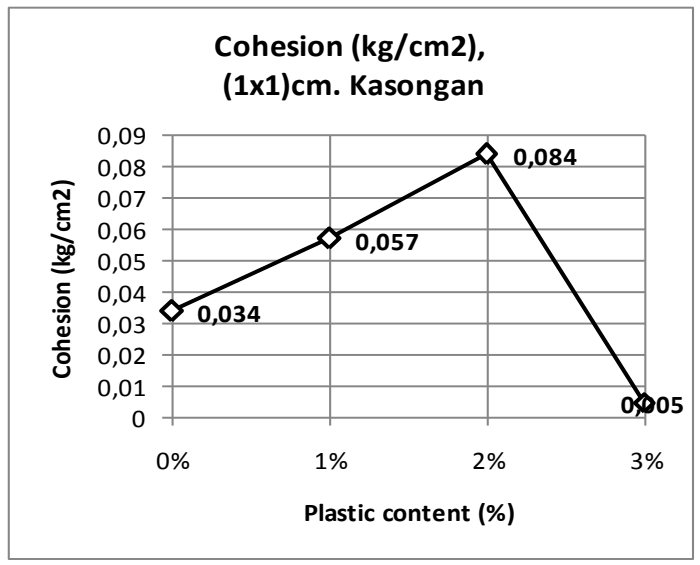

Fig. 15.

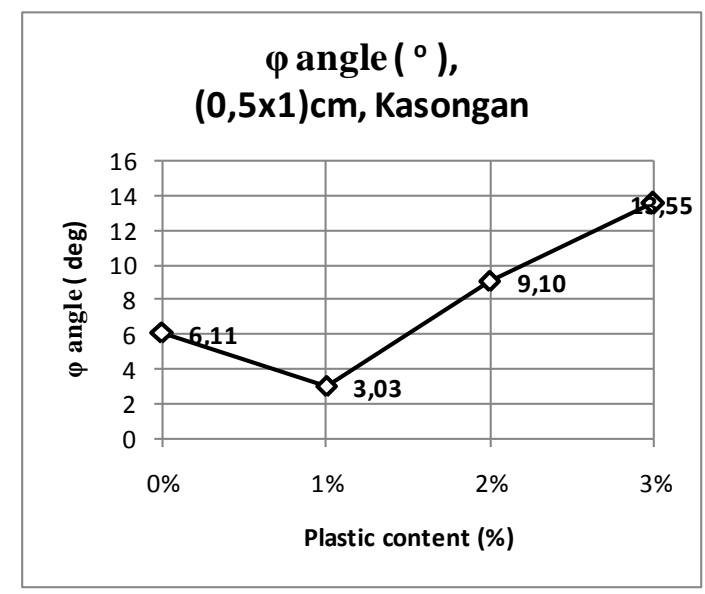

Fig. 16.

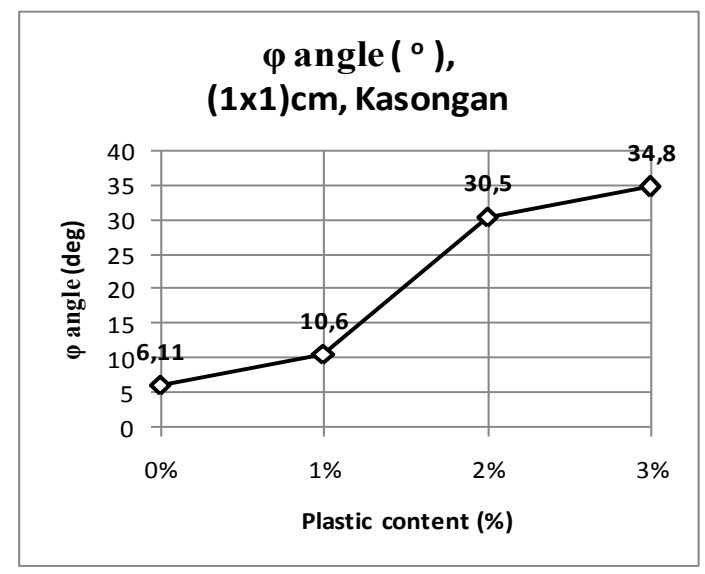

Fig. 17.

Fig. 14-17. The Result of Direct Shear Test of Kasongan Clays

Based on shear strength test on clays from Kasongan, it indicates that:
1. The cohesion-adhesion will increasing then decreasing in addition of plastics content. The highest adhesion occurs when the optimum plastics content is $1 \%-2 \%$.

2. Internal friction angle $(\varphi)$ will increased proportionally in addition of plastics content, especially if the size of the plastics are large $(1 \mathrm{~cm} \mathrm{x1} \mathrm{cm).} \mathrm{It} \mathrm{happened} \mathrm{because}$ of large number of plastics content eventually have a lot jagged edges that lead to increasing the clay's shear strength.

\section{CONCLUSIONS}

1. Increasing the plastics waste cuts on clays will caused:

a. On clay from Kasongan : qu will decreasing a little when the plastics content are $0 \%$ to $2 \%$, however qu tends to increase when the plastics content is $3 \%$.

b. On clay from Wates : qu will increasing if the plastics mixture are the large cuts $(1 \mathrm{~cm} \mathrm{x} 1 \mathrm{~cm})$, but qu tends to decrease if the plastics are the small cuts $(0.5 \mathrm{~cm} \times 1 \mathrm{~cm})$.

2. Increasing the plastic waste cuts on clays will caused:

a. On clay from Kasongan: internal friction angle $(\varphi)$ will increasing proportionally in addition of jagged edged plastics cuts.

b. On clay from Wates: internal friction angle $(\varphi)$ will decreasing if the mixture if the plastics waste are small cuts $(0.5 \mathrm{~cm} \times 1 \mathrm{~cm})$, however it will increasing a little if the cuts are the larger ones $(1 \mathrm{~cm} \mathrm{x} 1 \mathrm{~cm})$.

3. Increasing the plastic waste cuts on clays will caused:

a. On clay from Kasongan: cohesion-adhesion (c) will increased then decreasing. The highest adhesion occurs when the plastics content are $1 \%-2 \%$.

b. On clay from Wates: cohesion-adhesion (c) will increasing if the mixture of plastics waste are in small cuts $(0.5 \mathrm{~cm} \mathrm{x} 1 \mathrm{~cm})$, however it will decreasing if the plastics are the larger ones $(1 \mathrm{~cm} \mathrm{x} 1 \mathrm{~cm})$.

\section{REFERENCES}

[1] ASTM D422 - 72, Standard Test Method for Particle-Size Analysis of Soil, 2007.

[2] ASTM D424 - 74, StandardMethod of Test for Plastic Limit of Soil, 1971.

[3] ASTM D698 - 70, Standard Test Methods for Laboratory Compaction Characteristics of Soil Using Standard Effort, 1989.

[4] ASTM D854 - 02, StandardTest Method for Specific Gravity of Soil Solids by Water Pycnometer, 2002.

[5] ASTM D 2166 - 85, Standard Test Method for Unconfined Compressive Strength of Cohesive Soil, 2008.

[6] ASTM D 2216 - 71, Standad Test Method for Laboratory Determination of Water (Moisture) Content of Soil and Rock by Mass, 1989.

[7] Fairuz Hilwa, "Utilization of Waste Plastics as Alternative Fuel Substitute for Oil", 2015.

[8] http://www.slideshare.net/wawashahab/pemanfaatan-limbah-plastiksebagai-bahan-bakar-alternatif-pengganti-minyak-bumi - Downloaded on the 10-2-2015.

[9] Ferrie Safaria, Soil improvement with Soil Mixing. STT Garut, 2004.

[10] Fitroh Fauzi Ridwan, et al., "Influence of glass Shredded Plastic Polypropylene (PP) Against Push Strength and Pull Strength Concrete" 
Landscape Journal Vol.2 No. 1 pp 24-37, Bekasi: Bekasi Islam University- 45, 2014.

[11] Hardiyatmo, Soil Mechanics-1.Ed.6th. Gramedia Pustaka Utama, Jakarta, 2002.

[12] K.Sa'diyah and Sri Rachmawati Juliastuti, Effect of Temperature on Catalytic Pyrolysis process Polipropilene Plastic Waste (PP), Paper FTI- ITS. Surabaya, 2012.

[13] Labib Naufaldi, "Empat-R (Reduce, Reuse, Recycle, Replace) untuk Mengurangi Sampah”. http/www.writinganythink.com, 2013.
[14] Mirzan Ludvian \& Dian Eksana Wibowo, "Stabilisasi Tanah Lempung Menggunakan Campuran Limbah Abu Sekam Padi dan Pasir dengan Metode Pemadatan”. Journal INERSIA, vol.13, no.1, p.66-75, Yogyakarta 2017.

[15] Sazuatmo, "Effect of Plastic Materials on Shear Strength of Clay in the" Journal of UBL-Civil Engineering, Vol. 2 No. 1 pp 110-115, Bengkulu: FT Unihaz, 2011. 